\title{
Analysis of Latent Heat Based High Temperature Solar Energy Storage Unit
}

\author{
Nagesh R Biradar*and S.H.Sarje \\ †Department of Mechanical Engineering, Imperial College of Engineering and Research, Pune, India \\ Accepted 15 June 2016, Available online 20 June 2016, Special Issue-5 (June 2016)
}

\begin{abstract}
The Phase change material based high temperature solar energy storage device is used to produce electricity by means of sterling engine or process heating application. The energy storage is taken place by means of exploitation of latent heat of fusion of material stored inside the tank system. The method is mainly chosen because its capacity to producing high energy density and store energy can be successfully extracted with small variation in temperature every time, which adds major advantage in the entire processing. The justification on selection made for phase change material is discussed; the layer of insulating material is applied over system under thermal consideration analysis and optimization. The application of layer depicts heat loss to surrounding and thus helps further major temperature. The paper shows comparison between results, one obtained via experimental set up, observation noting, calculation performed and other by computer simulation, where the process is centric about computerized model formed and performance evaluation measure of real time prototype system.
\end{abstract}

Keywords: Latent Heat, Phase change Materials, Solar Thermal Energy storage, Caustic Potash, Specific Heat, Thermal Conductivity.

\section{Nomenclature}

TES Thermal energy storage

$\rho \quad$ Density

m Mass

V Volume

Cp Specific heat capacity

$\mathrm{k} \quad$ Thermal conductivity

$\mathrm{KoH}$ Potassium Hydroxide

CCHP Combined cooling and Heating

\section{Introduction}

An increased energy consumption worldwide and environmental awareness led to quote need of use renewable energy sources supposed to be less pollutant and environmental friendly.

Solar energy can be considered in the context fulfillment as mentioned above, added with further advantages like environmentally clean, abundant etc. The availability of solar energy is strongly influenced by the factors like seasonal and atmospheric condition of the respective geographical location. The performance versatility can be noted down different during day and night time, in day time it is available to the extent fulfilling all needs come arrive but the appearance of same found null and void during night

*Corresponding author: Nagesh R Biradar time. The need to overcome limitation comes arrive, come to notice, storage of solar energy to use it by the time of scarcity.

Power generation using solar energy is mainly undertaken by two methods and can be named as,

Thermal method: The solar radiations are concentrated to heat the fuel used for further application purpose

Photovoltaic method: The radiations are used to generate current electricity by means of solar cells. The solar cell can be used during day time and its work capability get hampers during night time, even use of battery is not economical at commercial basis and thus 'Solar Thermal Approach' is the better alternative can be considered at such fronts.

Present time the use of solar concentration systems such as parabolic trough and solar power towers for storing the heat in molten salts is getting popular widely. The only disadvantage of such systems to use is requirement of huge land in the set up installation and additional accessories like compound piping and pumping systems used to restrict temperature losses occurred and corrosion. The system mentioned earlier requires a lively sun tracking for entire day and going to increase the cost and system complexity as well.

This research work proposes use of Thermal Energy Storage Unit to overcome various limitations 
come existed with respect to old system and respective moving approach.

\section{Thermal Energy Storage Methods:}

The storing of thermal energy can be summarized under three different methods and elaborated further. First two methods are widely used to store thermal energy and can be named as sensible heat storage, Latent heat storage. Third and quite popular method is Thermochemical storage.

Liquid-gas conversions contain huge amounts of phase changing heat; however the huge density changes taken place during invent the system difficult to materialize to gain definite output from it onwards, and that is the reason, why solid to liquid phase change is replaced by and work approach of which is just discussed below.

In latent heat storage approach, the material is heated to phase change generally turn liquid from solid phase. During phase change occur material reach to fusion temperature and absorbs very large amount of heat leading material phase change, and that is how energy storage will be taken place.

The phase change material should with bunch of basic properties like thermo physical, chemical and kinetics etc.

The PCM consider for experimental analysis is, article Potassium Hydroxide (KoH) and also known as Caustic Potash. The Thermophysical properties listed in Table 1.

Table1 Thermophysical Properties of PCM (Caustic Potash

\begin{tabular}{|c|c|c|}
\hline Sr. No. & $\begin{array}{c}\text { Performance affecting } \\
\text { Parameters }\end{array}$ & $\begin{array}{c}\text { Values and quantity } \\
\text { measuring units }\end{array}$ \\
\hline 1 & Density & $2120 \mathrm{~kg} / \mathrm{m}^{3}$ at $25^{\circ} \mathrm{C}$ \\
\hline 2 & Melting point & $380^{\circ} \mathrm{C}$ \\
\hline 3 & $\begin{array}{c}\text { Thermal } \\
\text { conductivity }\end{array}$ & $0.5 \mathrm{w} / \mathrm{mk}$ \\
\hline 4 & Specific Heat & $1.1739 \mathrm{~kJ} / \mathrm{Kg} \mathrm{k}$ at \\
& $25^{\circ} \mathrm{C}$ \\
\hline 5 & Heat of Fusion & $149.7 \mathrm{~kJ} / \mathrm{kg}$ \\
\hline
\end{tabular}

\section{Experimental setup and Working:}

The design of a thermal energy storage unit can be divided in to two sections as, first is, the materials research part related to storage media selection, and the second one is, design of the heat transfer components and structuring the PCM.

The TES unit consists of TES material, receptortransmitter structure of energy, container for the TES material, thermal insulation to reduce the heat loses and a steel container to provide mechanical support to entire TES unit.

At average requirement level the TES unit is expected to assemble to perform for the set of characteristics like, nontoxic, chemical alert but no side effects during performance, chemically stable, little variation in the volume noted down as TES material receives or releases the energy at frequent basis, high value of latent heat or sensible heat per unit of mass or per unit volume, high thermal conductivity, available abundantly, low cost, long reliable and compatible with TES container.

The container should built with set of few characteristics on mandatory basis and they can be briefed as, little variation in the volume with respect to change in temperature, thin wall as long as possible, chemically stable, nontoxic, noninflammable, material used in designing should environment friendly and available at less cost.

The receptor and transmitter of energy needs to have high thermal conductivity, rate of absorption of solar radiation should as high as possible (High coefficient of thermal absorption with very less loss of energy to occurred to surrounding), chemically stable during high temperature circumstances and when comes in environmental contact.

The TES unit receives heat from gas furnace with air blower and then the temperature of TES unit is measured by temperature indicator as shown in fig. 1

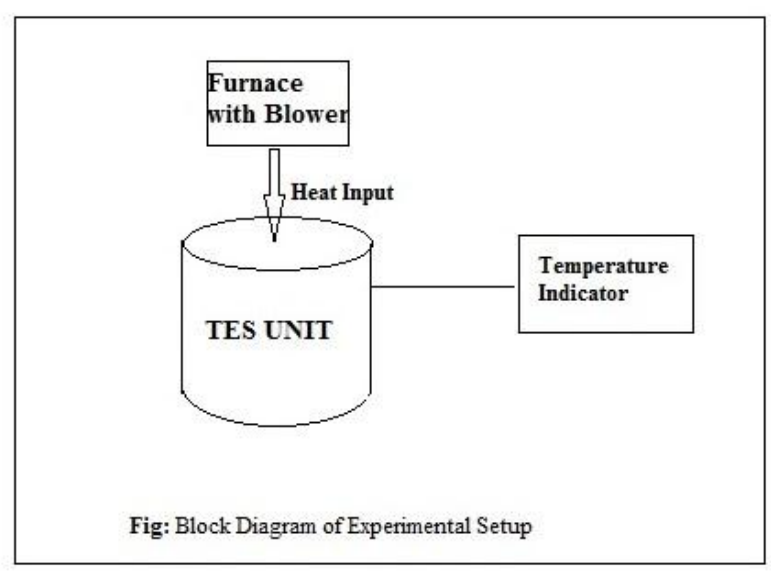

Fig.1 Block diagram of Experimental setup

The built prototype modeled with specifications such as, material caustic potash as PCM, copper as a receptor - transmitter of energy and its properties shown in Table 2.

Table2 Thermophysical Properties of Copper

\begin{tabular}{|c|c|c|}
\hline Sr. No. & $\begin{array}{c}\text { Performance affecting } \\
\text { Parameters }\end{array}$ & $\begin{array}{c}\text { Values and quantity } \\
\text { measuring units }\end{array}$ \\
\hline 1 & Density & $8960 \mathrm{~kg} / \mathrm{m}^{3}$ at $20^{\circ} \mathrm{C}$ \\
\hline 2 & Melting point & $1083^{\circ} \mathrm{C}$ \\
\hline 3 & $\begin{array}{c}\text { Thermal } \\
\text { conductivity }\end{array}$ & $401 \mathrm{w} / \mathrm{mk}$ at $20^{\circ} \mathrm{C}$ \\
\hline 4 & Specific Heat & $383.48 \mathrm{~J} / \mathrm{Kg} \mathrm{k}$ at $20^{\circ} \mathrm{C}$ \\
\hline 5 & $\begin{array}{c}\text { Thermal Expansion } \\
\text { Coefficient }\end{array}$ & $15.40^{*} 10^{-6} \mathrm{~m} / \mathrm{m}-\mathrm{k}$ \\
\hline
\end{tabular}

TES container crucible steel is internally lined with high refractory Zircon based material, thermal insulation of ceramic wool of $0.2 \mathrm{M}$ thickness is used to avoid heat dissipation to surrounding which is covered by steel container as shown in fig 2 . 


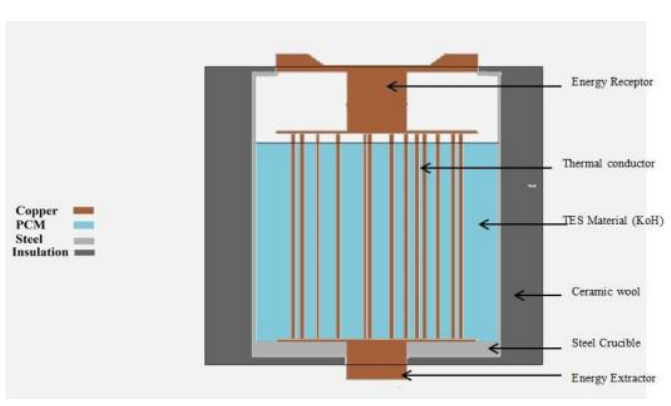

Fig.2 Prototype of Thermal Energy Storage (TES) Unit

The copper is showing some oxidation at surface exposed to air but having an excellent thermal conductivity and so it is selected as an energy receptor and transmitter. The selected PCM is moderately corrosive with copper but possesses good Thermophysical properties as per the requirement and ensure its availability at enough possible extent and thus chosen in to experimental work.

When operating within the CCHP system there is no charging period only, instead charging and discharging are simultaneous. During daylight hours, approximately 8 hours or $1 / 3$ day, the storage unit receives energy; it is responsibility of the internal thermal conductor to allocate $2 / 3$ of the received energy to the PCM for it to absorb and store for supporting the operation during night-time (the remaining $2 / 3$ of the day) and to let $1 / 3$ of the heat to flow freely for the Stirling engine to keep generating electricity or for process heating. In other words, during daytime the unit is charged while being discharged at a slower rate, meanwhile during nighttime the unit is purely discharged.

\section{Mathematical Model}

The variation of Thermal conductivity and specific heat of Copper with respect to temperature is linked and are expressed through following relationship,

$K=420.75-6.8493 * 10^{-2} T$

$C_{p}=316.21+0.3177 T-3.4936 * 10^{-4} T^{2}+1.661 *$

$10^{-7} T^{3}$

\section{Results and Discussion}

The built TES unit has capacity of storage 10 lit of caustic potash $(\mathrm{KOH})$ and work temperature is $325^{\circ} \mathrm{C}$ or beyond even. The variation in thermal conductivity and specific heat for copper probably we will get by using the equation $1 \& 2$ and the graph shown in fig3.

To measure the temperature at various locations during charging and discharging of prototype, integrated with 10 (K-Type) Thermocouples. T1 is placed at receptor to measure the input temperature and $\mathrm{T} 2$ is placed just above to the upper plate, T10 at energy extraction zone and T3 to T9 are immersed in PCM maintained for different height and depth and all together are arranged in in circumferential manner.

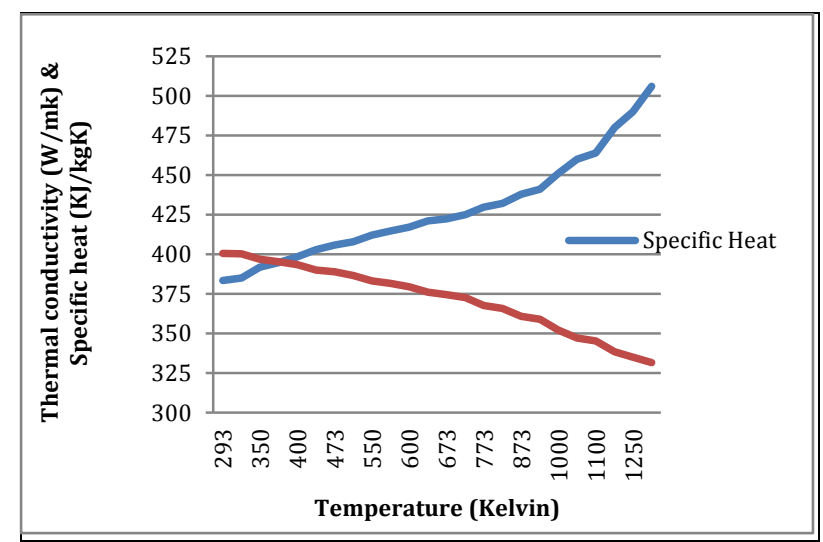

Fig.3 Graph showing relation between, Temperature, Thermal Conductivity and Specific heat of Copper

For experimental testing the TES unit has heated by gas furnace for 9 hours in continuation. During heating, observations were noted down for more than 10 different places on the prototype with prescribed gap of 30 minutes maintained during each subsequent observation made as such. The work is executed in the said manner to study the behavior in terms the function of the energy input given. Figure $4 \& 5$ shows a graph of such measurements taken during experiment; it is the result ten thermocouples considered most important during experimentation work.

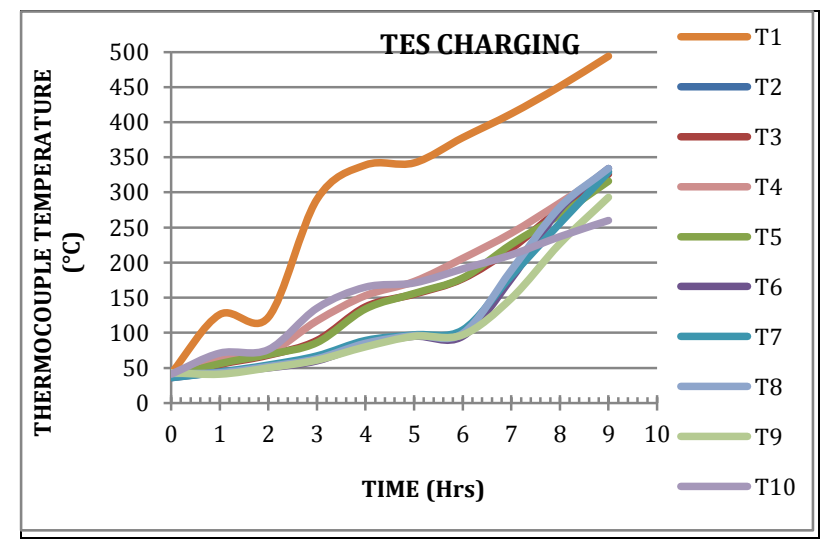

Fig.4 Characteristic graph showing behavior of Prototype heating process

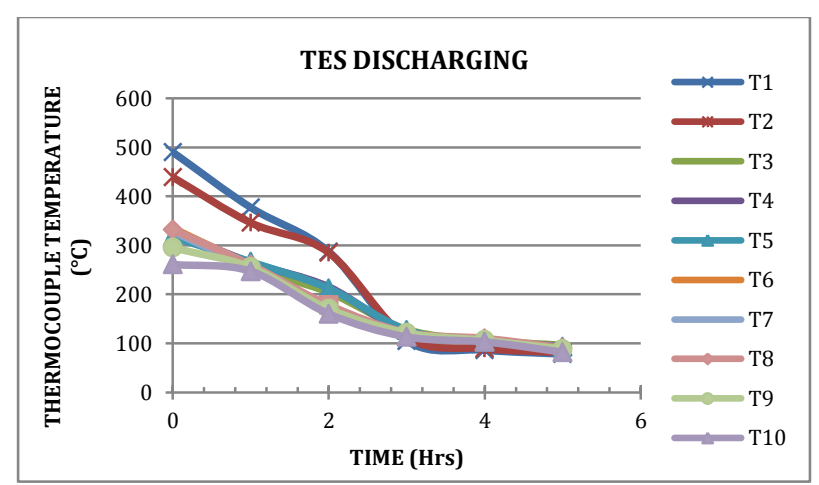

Fig.5Characteristic graph showing behavior of Prototype cooling process 


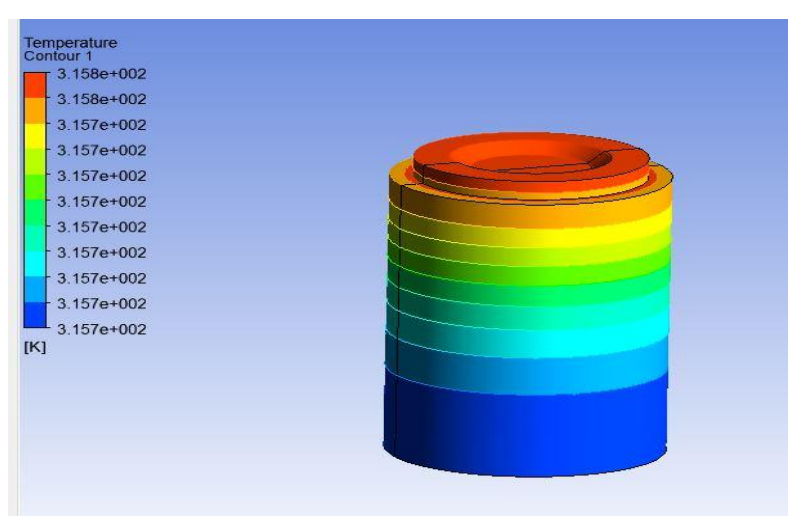

Fig.6 Computer simulation of temperature distribution inside TES unit

\section{Conclusion}

Solar Thermal energy storage is a promising technology to address raised energy demand in the future and thus solar thermal plants have demonstrated, it is easier and cheaper way to store heat in thermal storage which can used further for process heating and electricity generation as well, and this all leading to increase an efficiency of solar system which keep operation running in continuation during day and night time as well.

Measurement reveals that, the internal thermal conductor is capable of maintaining a very low temperature difference between the PCM placed within top region of container and bottom of container as well.

The unit capable of storing $2 \mathrm{KWh}$ of energy and the temperature at various locations during observation is compared with simulation result and shows less deviation between experimental and simulation results.

Thermal performance can be increased by metallic fins, extended surfaces and high conductivity particles which are dispersed in PCM.

For increasing efficiency, The TES unit should provide with an insulation which would minimize energy losses occurred to surroundings.

\section{References}

Medrano M, et al (2010), State Of The Art On High Temperature Thermal Energy Storage For Power Generation, Renewable and sustainable Energy Reviews, 14:56-72.

Trombe F, et al (1973), Thousand KW Solar Furnace, Built By The National Center Of Scientific Research In Odeillo (France), Solar Energy, 15(1), 57-61.

Kronhardt V, et al (2014), High Temperature Thermal Energy Storage System For Solar Tower Power Plants With Open Volumetric Air Receiver Simulation And Energy Balancing of A Discretized Model. Energy Procedia, 49(2014)870 - 877.

Lane G.A (1983), solar heat storage: latent heat material, Background and scientific principles: Florida-CRC press, Vol. I.

Abhat A, (1981), Low temperature latent heat thermal energy storage: heat storage materials, solar energy 1981; 30(4):313-32.

Buddhi D, et al, (1994), Proceedings on thermal energy storage and energy conversion

Pilkington Solar International Survey of Thermal Storage for Parabolic Trough Power Plants Report, NREL1EC24, (2002)

Amador B, (2012), Materiales de cambio de fase para almacenamiento de energia solar, Instituto technologico y de Estudios Superiores de Monterrey, Nuevo León, México.

J. Phys. Chem. Ref. Data, Vol. 13, No. 4, (1984) pg 1252.

Frank P. Incropera, Fundamentals of Heat and Mass Transfer. Second Edition.

$\mathrm{T}$ J. Miller. Strength and Fatigue of DispersionStrengthened Copper. Journal of Nuclear Materials, 179 - 181, pg 263 - 266, North-Holland.

Handbook of Chemistry and Physics, First Edition, CRC Press, pg 12 - 108.

Ramon Gutierrez, (2015), Material Selection For Latent Heat Based High Temperature Solar Thermal Energy Storage, Energy Procedia 74 (2015) 1525 - 1532.

Cardenas, B. (2014). High Temperature Solar Thermal Energy Storage, Instituto Technologico y de Estudios Superiores De Monterrey, Nuevo Leon, Mexico. 